\title{
MICROALGAL FLOCCULATION OF CHLORELLA VULGARIS BY ALTERATION OF $\mathrm{pH}$
}

\author{
Magesh Peter D. ., Mehumuna Begum ${ }^{2}$, Mary Leema Thilakam J., Vinith Kumar N. V, Kirubagaran R, \& Kathiroli. S. \\ ${ }_{1,2,3}$ National Institute of Ocean Technology, \\ (Ministry of Earth Sciences, Government of India) Dollygunj, Port Blair - 744103,Andaman \& Nicobar Islands \\ Email: magesh1@yahoo.com
}

\begin{abstract}
Flocculation of chlorella vulgaris using $\mathrm{NaOH}$ in the $\mathrm{pH}$ range 8.5 to 11.00 was studied and the cell counts of $399 \times 10^{-4}$ with a turbidity of $0.353 \mathrm{OD}_{600}$. The flocculation efficiency is very sensitive to $\mathrm{pH}$ and the cell concentration. The results of the algal flocculation by $\mathrm{pH}$ alteration were very effective at $10.38 \mathrm{pH}$ on $14^{\text {th }}$ day of the incubation of the culture and reached the flocculation efficiency upto 98.50 ü $0.34 \%$ with recovery of total lipid upto $94.44 \%$.
\end{abstract}

KEYWORDS: Flocculation, Chlorella, Flocculation efficiency, Flocculation activity, Microalgae.

\section{INTRODUCTION}

The flocculating reactions of an algal biomass are particularly sensitive to the $\mathrm{pH}(1 \& 14)$. The removal of algae from the mass culture by flocculation has been investigated. In this present study the flocculation of the chlorella cells by altering the $\mathrm{pH}$ with $\mathrm{NaOH}$ was studied. However use of this flocculated microalga has several applications including the utilization of cultivated cells for the production of biodiesel and other nutroceutical products. Thus similar to other species of algal cultivation this method of cost effective harvest of microalgae by flocculation process will be effective and practical for removing the suspended cells from the culture broth.

Microalgal cells carry negative charge that inhibits aggregation of cells in a culture broth. Ideally, the flocculants used should be inexpensive, nontoxic, and effective in low concentration. In addition, the flocculant should be selected so that further downstream processing is not adversely affected by its use (4). Effect of alkali $\mathrm{NaOH}$ on cell removal by flocculation from suspensions of Chlorella is been investigated in this work (16).

\section{MATERIALS AND METHODS}

\section{A. Culturing media}

Molar concentration of $f / 2$ Medium and Derivatives in final medium for major nutrients $\mathrm{NaNO}_{3}-8.83 \times 10^{-4} \mathrm{M}$, $\mathrm{NaH}_{2} \mathrm{PO}_{4}{ }^{\prime} \mathrm{H}_{2} \mathrm{O}-3.63 \times 10^{-5} \mathrm{M}, \mathrm{Na}_{2} \mathrm{SiO}_{3}{ }^{\prime} 9 \mathrm{H}_{2} \mathrm{O}-1.07 \times 10^{-4} \mathrm{M}$; Trace metal solution of $\mathrm{FeCl}_{3}{ }^{\prime} 6 \mathrm{H}_{2} \mathrm{O}-1 \times 10^{-5} \mathrm{M}$, $\mathrm{Na}_{2}$ EDTA $^{\prime} 2 \mathrm{H}_{2} \mathrm{O}-1 \times 10^{-5} \mathrm{M}$, CuSO ${ }_{4}^{\prime} 5 \mathrm{H}_{2} \mathrm{O}-4 \times 10^{-8} \mathrm{M}$, $\mathrm{Na}_{2} \mathrm{MoO}_{4}{ }^{\prime} 2 \mathrm{H}_{2} \mathrm{O}-3 \times 10^{-8} \mathrm{M}, \mathrm{ZnSO}_{4}{ }^{\prime} 7 \mathrm{H}_{2} \mathrm{O}-8 \times 10^{-8} \mathrm{M}$, $\mathrm{CoCl}_{2}{ }^{\prime} 6 \mathrm{H}_{2} \mathrm{O}-5 \times 10^{-8} \mathrm{M}, \mathrm{MnCl}_{2}{ }^{\prime} 4 \mathrm{H}_{2} \mathrm{O}-9 \times 10^{-7} \mathrm{M}$; vitamin Solution of Vitamin $\mathrm{B}_{12}$ (Cyanocobalamine) $-1 \times 10^{-10} \mathrm{M}$, Biotin - $2 \times 10^{-9} \mathrm{M}$, Thiamine' $\mathrm{HCl}-3 \times 10^{-7} \mathrm{M}$. (7 \& 8). The culture was grown in Erlenmeyer's flask - $2000 \mathrm{ml}$ under cool white fluorescent illumination of approximately $563 \mathrm{ft}-\mathrm{c}$ intensity at $25 \cdot \mathrm{C}$.

\section{B. Growth Determination}

The growth of the batch culture was measured tubidometrically using UV visible double beam spectrophotometer (Thermospectronic) at the wavelength of $660 \mathrm{~nm}$. (10). The growth of the batch culture was also measured by cell counts using Neubaeur's cell counter under microscope (6 \&13)

\section{Sampling procedure}

A microalgae culture $100 \mathrm{ml}$ aliquots of culture of chlorella was taken into $250 \mathrm{ml}$ baker and the $\mathrm{pH}$ was adjusted by the addition of $1 \mathrm{M} \mathrm{NaOH}$ solution and the $\mathrm{pH}$ was measured with a bench top $\mathrm{pH}$ meter (Thermo Orion) with 0.01 accuracy. In This study the chlorella culture has been adjusted the pH 8.50, 9.50, 10.38, 10.50 \& 11.00. The $\mathrm{pH}$ adjusted culture of chlorella was then transferred immediately into a $100 \mathrm{ml}$ class-A measuring cylinder. The aliquots of samples were retrieved from the $100 \mathrm{ml}$ measuring cylinder for every 10 minutes and measured for turbidity in spectrophotometer at $\mathrm{OD}_{660}$. Algal cell concentrations were determined turbidometrically by spectrophotometer and cell counts/ $\mathrm{ml}$ using Hemocytometer.

Microalgal cells possess negative charges that prevent assemblage of cells in suspension. Infact the aim behind this study is ideally, the flocculants used should be inexpensive, nontoxic, and effective in low concentration. Moreover, the flocculant chemical which is been to be used is selected so that further downstream processing is not adversely affected by its use (4).

\section{Flocculation efficiency}

Flocculation efficiency as calculated by the following equation, flocculation efficiency $(\%)=(1-A / B) \times 100, A$ : $\mathrm{OD}_{660}$ of sample, $\mathrm{B}: \mathrm{OD}_{660}$ of reference (without flocculant). ( $3 \& 9)$. The flocculation of batch settling is shown in the form of settling curve Fig. (4 - 11) at different 
concentrations and at different $\mathrm{pH}$ conditions. Settling curve is indicated as the ratio of the final volume $(V)$ to the initial volume $\left(V_{0}\right)(10)$.

$$
\begin{gathered}
\text { Settling ratio }=V / V_{0} \\
\text { where } V=\text { Final volume and } V_{0}=\text { Initial volume }
\end{gathered}
$$

\section{E. Total lipid estimation}

The flocculated microalgal cells were macerated in a tissue homogenizer with chloroform-methanol $(2: 1, \mathrm{v} / \mathrm{v})$ and transferred to a separating funnel. Lipids were extracted, and separated into chloroform and aqueous methanol layers by the addition of methanol to give a final solvent ratio of chloroform : methanol of $2: 1$ is a modification of the method by Bligh and Dyer. The chloroform layer was washed with $20 \mathrm{ml}$ of $0.6 \% \mathrm{NaCl}$ solution, and evaporated to dryness, total lipids were measured gravimetrically (2).

\section{RESULTS}

The flocculation of microalgae was not effective under the acidic $\mathrm{PH}$ condition. However by the increasing the $\mathrm{pH}$ remarkably floc formation occurred and it rapidly started settling. A batch settling experiment using chlorella culture with the same batch culture was investigated on $2^{\text {nd }}$, $4^{\text {th }}, 6^{\text {th }}, 8^{\text {th }}, 10^{\text {th }}, 12^{\text {th }}, 14^{\text {th }}$ and $16^{\text {th }}$ day at different cell concentration levels. The settling was completed with an hour. During the $2^{\text {nd }}$ and $4^{\text {th }}$ day at $\mathrm{Ph} 8.50,9.50,10.38$ \&10.50there algal flocs did not occur and $\mathrm{pH} 11.00$ started forming floc. But the cell culture when it reached the $16^{\text {th }}$ day the cell count was $398.5 \times 10^{-4} \mathrm{cell} / \mathrm{s} / \mathrm{ml}$ of culture. There was no floc formation or settling were observed at $\mathrm{pH} 8.50$ and $\mathrm{pH} 9.50$ of algae, at pH 11.00 also there was floc formation but they remain suspended in the media. At pH 10.50 also there was floc formation nevertheless the settling velocity was slower than settling by $\mathrm{pH} 10.38$. It is suggested that flocculation leads to the high recovery of micro algal cells for effective utilization.

\section{Discussion}

The rise in the culture $\mathrm{pH}$ using $\mathrm{NaOH}$ accelerated the mass settlement of algae which made the harvest of algae easier. The removal efficiency increased as the cell concentration increased (5). Thus the algal flocculation with $\mathrm{NaOH}$ is most effective at high $\mathrm{pH}$ 10.38.A distinct stoichiometric relationship is investigated between algal cell concentration and requisite $\mathrm{pH}$ with time. The optimal microalgal flocculation is late log phase and the early declining growth phase (12). The flocculation efficiency upto 98.50 ü $0.34 \%$ which was higher than the $72 \%$ and 78 $\%$ produced by aluminium sulphate and polyacylamide (9). Thus the $\mathrm{NaOH}$ can be used effectively to harvest chlorella vulgaris from large-scale cultures.

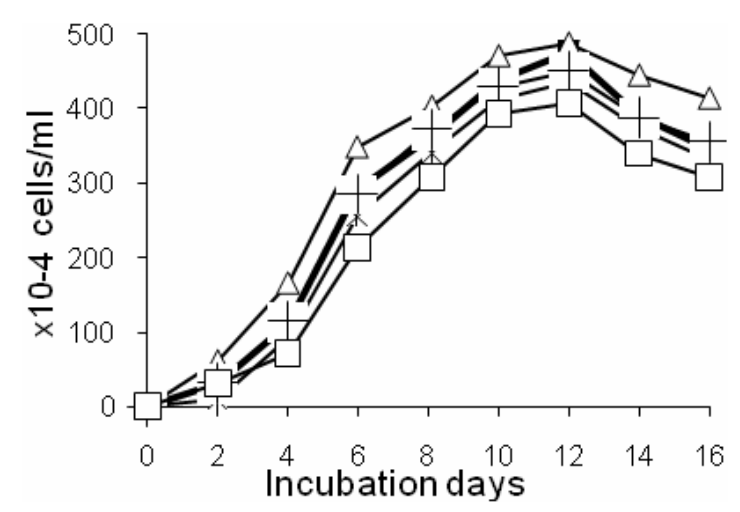

Fig. 1. Growth curve of chlorella vulgaris was observed in seven set of batch culture.

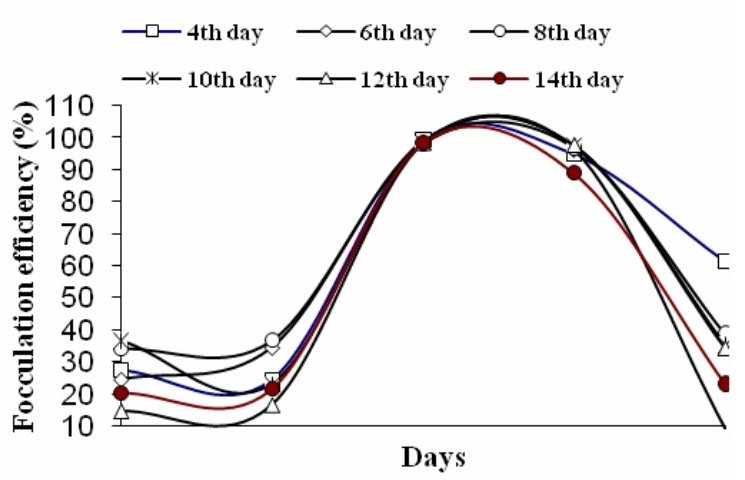

Fig. 2. Flocculation efficiency curve, Flocculation efficiency $(\%)=(1-A / B) \times 100, A: O_{660}$ of sample, $B$ : $\mathrm{OD}_{660}$ of reference

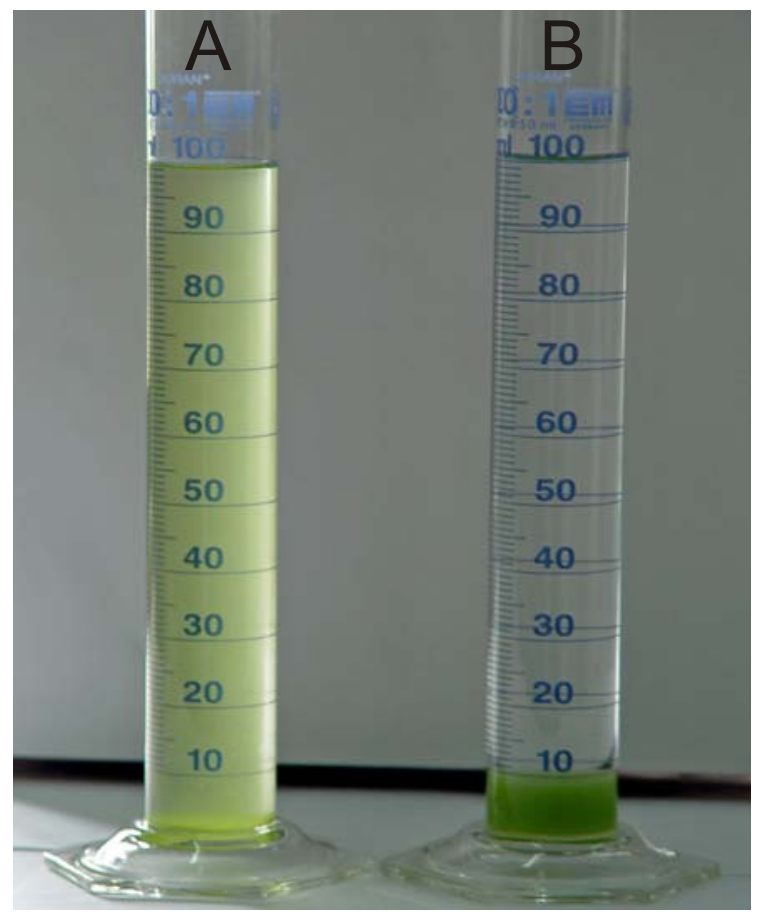

Fig. 3a. Flocculation of $C$. vulgaris (A) - Control without $\mathrm{pH}$ adjustment with $\mathrm{NaOH}(\mathrm{E})-$ Flocculated with $\mathrm{NaOH}$ at $10.38 \mathrm{pH}$ 


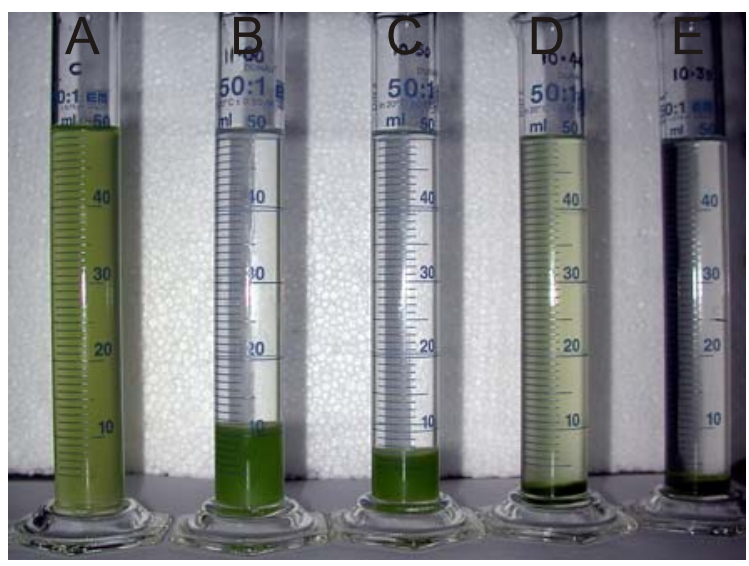

Fig. 3b. Flocculation of $C$. vulgaris at different pH adjustment with $\mathrm{NaOH}(A)-$ Control; $(B)-11.00 \mathrm{pH}$; (C) - $10.50 \mathrm{Ph}$; (D )$-10.40 \mathrm{pH} \&(\mathrm{E})-10.38 \mathrm{pH}$
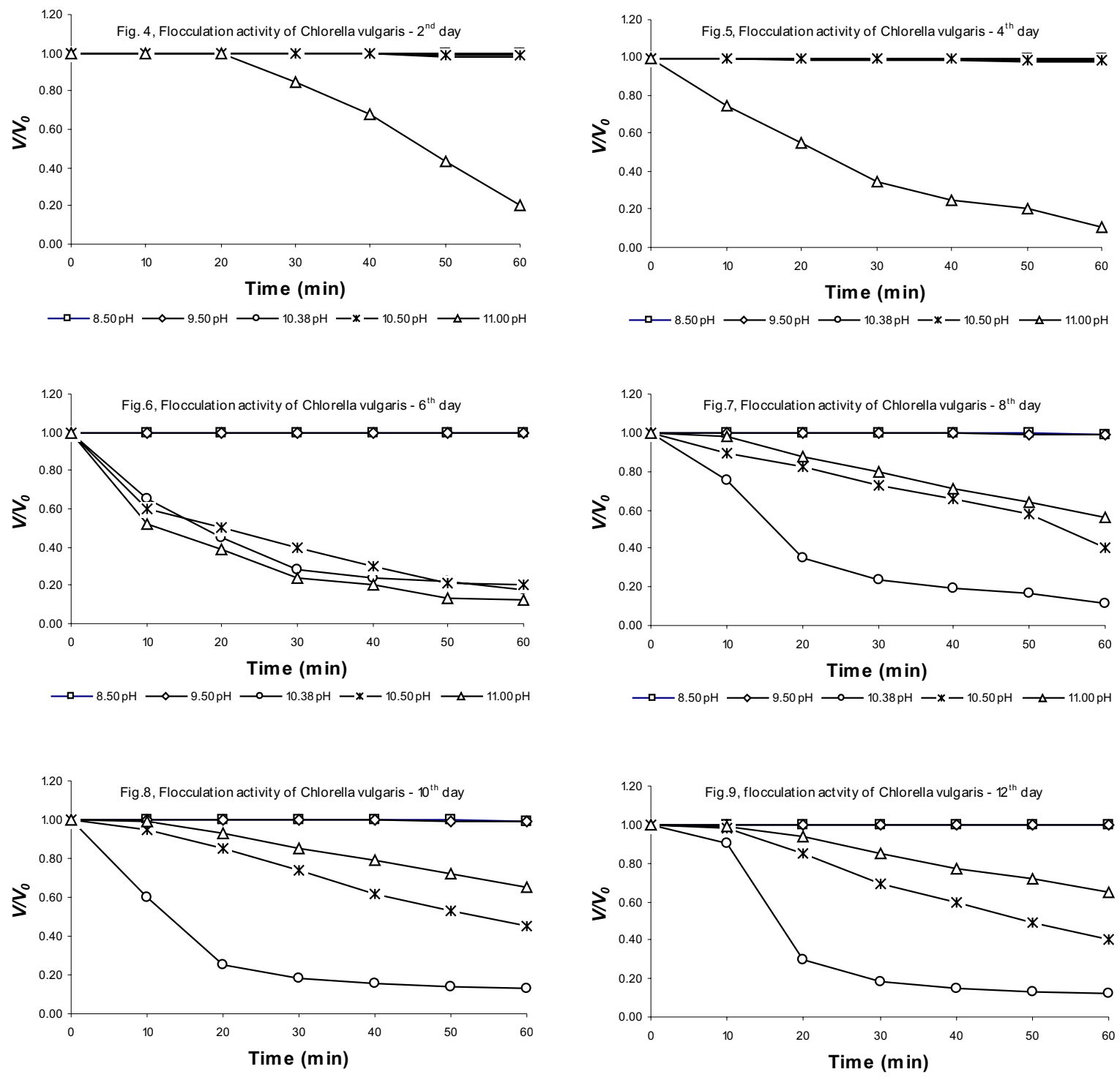

$\longrightarrow-8.50 \mathrm{pH} \longrightarrow 9.50 \mathrm{pH} \longrightarrow-0-10.38 \mathrm{pH} \longrightarrow \mathbf{x}-10.50 \mathrm{pH} \longrightarrow-11.00 \mathrm{pH}$

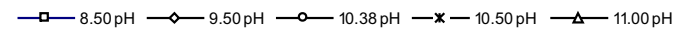



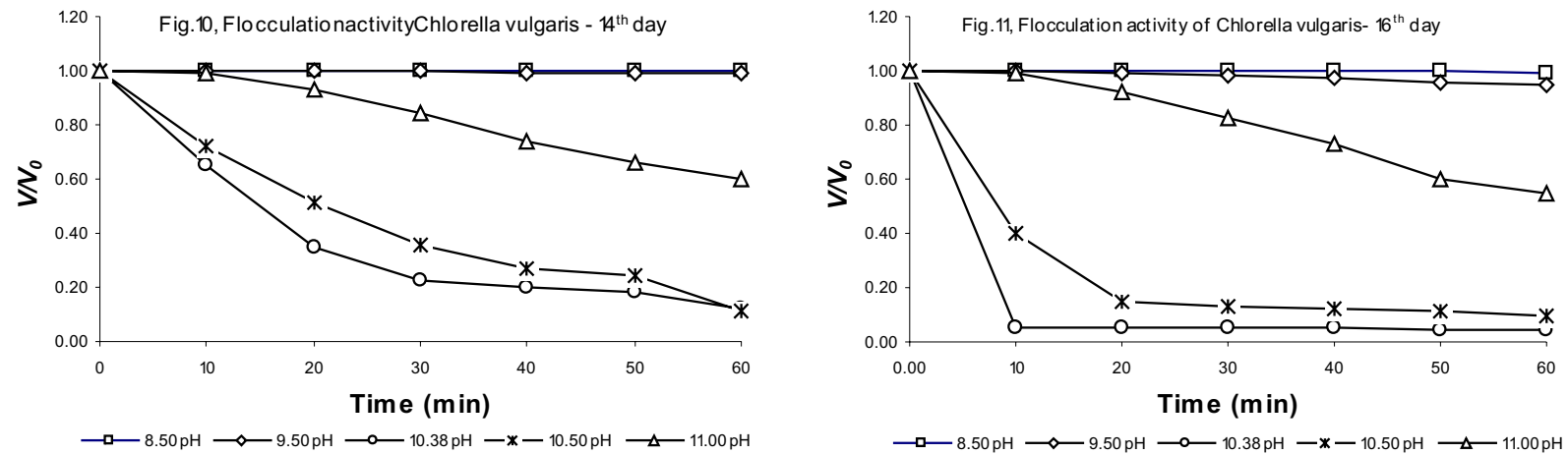

Fig. 4 - 11 Shows Settling curve of Chlorella vulgaris under various cell concentrations and at different pH conditions. Settling curve is indicated as the ratio of the final volume $(V)$ to the initial volume $\left(V_{0}\right)$.

Table 1. Percentage of total lipid content recovery at different $\mathrm{pH}$

\begin{tabular}{|l|l|l|}
\hline Sample & $\begin{array}{l}\text { Total lipid } \\
\text { (gms/100ml) }\end{array}$ & $\begin{array}{l}\text { \% of lipid } \\
\text { recovery }\end{array}$ \\
\hline Control & 0.018 ü 0.005 & $100.00 \%$ \\
\hline $\mathrm{pH} 8.50$ & 0.007 ü 0.005 & $38.89 \%$ \\
\hline $\mathrm{pH} \mathrm{9.50}$ & 0.005 ü 0.005 & $71.43 \%$ \\
\hline $\mathrm{pH} \mathrm{10.38}$ & 0.017 ü 0.005 & $94.44 \%$ \\
\hline $\mathrm{pH} 10.50$ & 0.012 ü 0.005 & $70.59 \%$ \\
\hline $\mathrm{pH} \mathrm{11.00}$ & 0.004 ü 0.005 & $33.33 \%$ \\
\hline
\end{tabular}

Table 2. Flocculation efficiency (\%) at various $\mathrm{pH}$ conditions

\begin{tabular}{|l|l|}
\hline $\mathrm{pH}$ & $\begin{array}{l}\text { Flocculation } \\
\text { efficiency (\%) }\end{array}$ \\
\hline 8.50 & 26.28 ü 7.57 \\
\hline 9.50 & 26.09 ü 7.13 \\
\hline 10.38 & 98.50 ü 0.34 \\
\hline 10.50 & 95.46 ü 3.06 \\
\hline 11.00 & 33.72 ü 5.82 \\
\hline
\end{tabular}

\section{REFERENCES}

[1] Bilanovic, D., Shelef, G. \& Sukenik, A. 1988. Flocculation of microalgae with cationic polymers; effect of medium salinity. Biomass 17: 65 76.

[2] Bligh, E.G. \& Dyer, D.J. 1959. A rapid method for total lipid extraction and purification.Can J.Biochem. Physiol. 37: 911-917.

[3] Buelna, G., Bhattarai, K.K., De la No\#e, J., Taiganides, E.P. 1990. Evaluation of various flocculants for the recovery of algal biomass growth on pig-waste. Biol. Wastes 31:211-222.
[4] Molina Grima E., Belarbi, E. H., AcieænFernaændez F.G., Robles Medina A., \& Yusuf Chisti. 2003. 


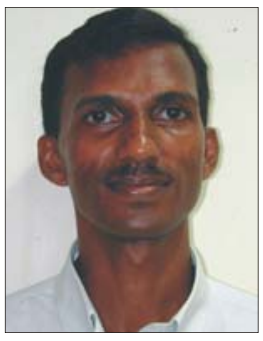

